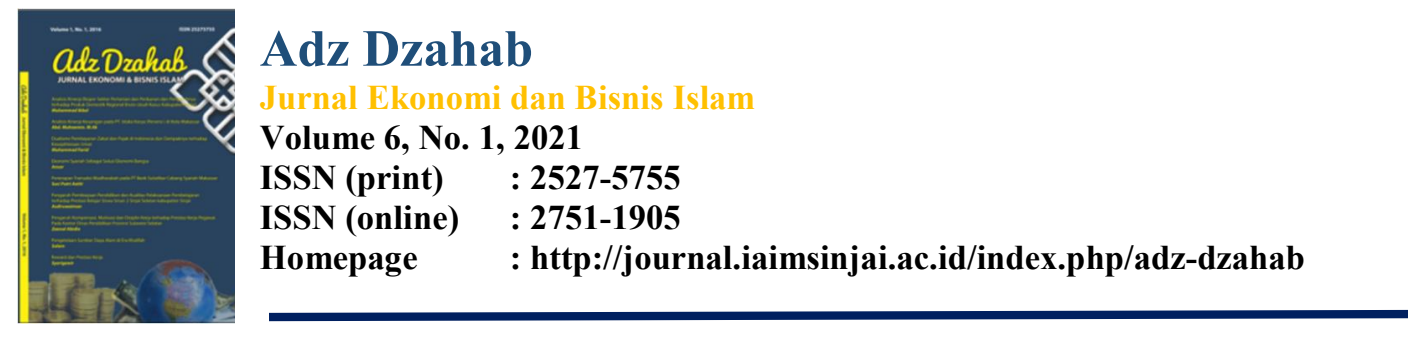

\title{
HARTA DALAM PERSPEKTIF EKONOMI ISLAM
}

\author{
Shalza Yashinta Mayseliandra ${ }^{1}$ \\ ${ }^{1}$ IAIN Ponorogo, Jl. Puspita Jaya, Krajan, Pintu, Kec. Jenangan, Ponorogo \\ Korespondesi Penulis. E-mail: shalzamayseliandra@gmail.com, Tlp: +6285704544123
}

\begin{abstract}
Abstrak
Al-Qur'an menyebut kata Al-Mal (harta) tidak kurang dari 86 kali. Penyebutan berulangulang terhadap sesuatu di dalam Al-Qur'an menunjukkan adanya perhatian khusus dan penting terhadap sesuatu itu. Harta merupakan bagian penting dari kehidupan yang tidak dipisahkan dan selalu diupayakan oleh manusia dalam kehidupannya terutama di dalam Islam. Tujuan penelitian harta dalam perspektif ekonomi Islam ini adalah untuk mengetahui prespektif ekonomi islam mengenai harta. Islam memandang keinginan manusia untuk memperoleh, memiliki, dan memanfaatkan harta sebagai sesuatu yang lazim, dan urgen. Harta diperoleh, dimiliki, dan dimanfaatkan manusia untuk memenuhi hajat hidupnya, baik bersifat materi maupun non materi. Metode yang digunakan dalam penelitian harta dalam perspektif ekonomi Islam ini adalah Jenis penelitian ini meliputi kombinasi antara penelitian pustaka (library research), beberapa data sekunder. Dengan metode tersebut kita dapat memahami akan kandungan hukum dan konsep harta dalam hukum ekonomi dan bisnis yakni harta sebagai fitnah ujian keimanan, hiasan hidup (perhiasan dunia), pegengan terhadap orang yang dapat mengelolanya.
\end{abstract}

Kata Kunci : aset, ayat Al-qur'an, asbabul nuzul, kandungan, peran

\section{Pendahuluan}

Harta dalam bahasa arab disebut al-maal, yang mempunyai arti condong, , cenderung, miring. Manusia cenderung ingin memiliki dan menguasai harta. Menurut Hanafiyah harta adalah sesuatu yang digandrungi oleh tabiat manusia dan memunkinkan untuk disimpan hingga dibutuhkan(Dinzaudin Djauwani,2008).

Dalam al-muhith dan lisan Arab, menjelaskan bahwa harta merupakan segala sesuatu yang sangat diinginkan oleh manusia untuk menyimpan dan memilikinya. Dengan demikian unta, kambing, sapi, tanah, emas, perak, dan segala ssuatu yang disukai oleh manusia dan memiliki nilai adalah harta.

Jadi pengertian Harta adalah suatu aset kekayaan kebendaan yang di butuhkan, di cari, dan di miliki oleh manusia. Harta juga sangat berguna bagi semua orang, karena dengan harta kekayaan manusia dapat memenuhi segala kebutuhan baik yang di inginkan atau yang sedang di butuhkan. Harta dapat menjadi kebahagiaan dunia dan akhirat apabila digunakan dalam hal yang benar, sebaliknya jika digunakan dalam hal yang salah maka akan menjadi suatu keburukan seperti hal nya pisau terkadang pisau dapat menolong dan terkadang dapat membunuh. Harta merupakan hal yang sangat penting bagi manusia karena dengan harta kita bisa memenuhi kebutuhan kita. Kita harus bisa mengelola harta kita dengan baik agar tidak salah dipergunakan dan mempergunakannya untuk hal yang bermanfaat.

Dengan demikian maka dapat di katakan bahwa semua manusia pastinya ingin selalu memperbanyak harta kekayaan dan selalu ingin memilikinya agar bisa menjadikan generasi penerusnya menjadi lebih baik. 


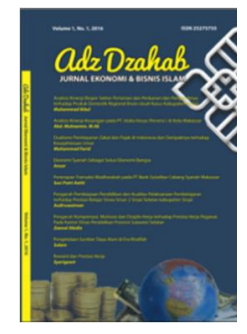

Adz Dzahab

Jurnal Ekonomi dan Bisnis Islam

Volume 6, No. 1, 2021

ISSN (print) : 2527-5755

ISSN (online) : 2751-1905

Homepage : : http://journal.iaimsinjai.ac.id/index.php/adz-dzahab

\section{Metode}

a. Jenis penelitian

Jenis penelitian ini meliputi kombinasi antara penelitian pustaka (library research), beberapa data sekunder. Penelitian pustaka dengan mengkaji dokumen-dokumen yang berhubungan dengan penelitian ini, berupa bahan dari narasumber, data yang diperoleh melalui buku-buku, jurnal ilmiah dan bahan tertulis lainnya.

b. Pendekatan penelitian

Penelitian studi kasus memusatkan diri secara intensif pada satu objek tertentu yang mempelajarinya sebagai suatu kasus. Penelitian studi kasus dimaksudkan untuk mempelajari secara intensif, tentang latar belakang masalah keadaan dan posisi suatu peristiwa atau objek analisis yang sedang berlangsung saat ini, serta interaksi lingkungan unit sosial tertentu yang bersifat apa adanya. Subjek penelitian dapat berupa individu, kelompok, institusi atau masyarakat(Imam Gunawan, 2013).

c. Subjek Penelitian

Adapun yang menjadi subjek pada penelitian ini adalah mengenai sudut pandang Alqur'an terhadap konsep harta dan juga prespektif harta dalam pandangan ekonomi islam.

d. Objek penelitian

Dalam penelitian ini, yang menjadi objek penelitian adalah harta, dimana harta atau bisa kita sebut uang selalu muncul dimana saja dan kapan saja. Namun dalam penggunaan yang berbeda beda di setiap orang.

e. Teknik pengumpulan data

Data sekunder

Data sekunder merupakan informasi-informasi yang dikumpulkan untuk kepentingan studi yang sedang dilakukan oleh peneliti untuk beberapa tujuan tertentu.

f. Instrumen Penelitian

Instrumen-instrumen penelitian merupakan alat bantu bagi peneliti dalam mengumpulkan data. Kualitas instrumen akan menentukan kualitas data yang terkumpul. Adapun instrumen yang digunakan pada penelitian ini yaitu sesuai dengan teknik pengumpulan data itu sendiri, dalam penelitian ini terdapat beberapa teknik pengumpulan data yaitu sebagai berikut:

Panduan observasi adalah alat bantu yang dipakai sebagai pedoman dari pengumpulan data pada proses penelitian.

g. Teknik Analisa Data

Teknik analisis dan interpretasi yang digunakan adalah teori Haberman dan Miles (Burhan Bungin,2009) teknik ini dikenal dengan istilah teknik pengolahan data interaktif. Analisis data adalah proses mencari dan menyusun secara sistematis data yang diperoleh dari hasil wawancara, catatan lapangan, dan dokumentasi, dengan cara mengorganisasikan data ke dalam kategori, menjabarkan ke dalam unit-unit, melakukan sintesa, menyusun ke dalam pola, memilih mana yang penting dan yang akan dipelajari, dan membuat kesimpulan sehingga mudah dipahami oleh diri sendiri maupun orang lain(Sugino,2010). Adapun tahap-tahap dalam penganalisaan data penelitian ini meliputi tiga tahap yaitu sebagai berikut:

1) Reduksi Data (Data Reduction)

Reduksi data, yaitu proses pengumpulan data yang kemudian dilakukan pemilahan, diklasifikasi, serta pemusatan perhatian pada penyederhanaan data. Karena itu data yang diambil adalah data-data yang berkaitan dengan permasalahan 


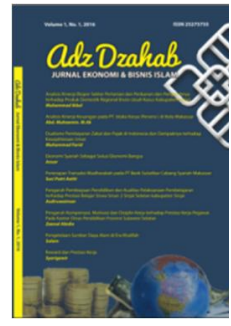

Adz Dzahab

Jurnal Ekonomi dan Bisnis Islam

Volume 6, No. 1, 2021

ISSN (print) : 2527-5755

ISSN (online) : 2751-1905

Homepage : http://journal.iaimsinjai.ac.id/index.php/adz-dzahab

yang diteliti. Penelitian ini berkaitan dengan penggunaan harta yang sesuai dengan perintah Allah dan juga pentingnya harta dalam ekonomi syariah.

2) Penyajian data (Data Display)

Setelah data direduksi, maka langkah selanjutnya adalah men-display data. Dalam penelitian kualitatif, penyajian data bisa dilakukan dlam bentuk uraian singkat, bagan hubungan antara kategori, flouchard dan sejenisnya.

3) Verifikasi (Conclusion Drawing)

Langkah ketiga yang harus dilakukan dalam analisis data kualitatif yakni penarikan kesimpulan dan verifikasi kesimpulan awal yang dikemukakan masih bersifat sementara, dan akan berubah bila tidak ditemukan bukti-bukti berikutnya. Tetapi apabila kesimpulan yang dikemukakan pada tahap awal didukung oleh buktibukti wild dan konsisten saat penulis kembali kelapangan mengumpulkan data maka kesimpulan yang dikemukakan merupakan kesimpulan yang kredibel.

\section{Hasil dan Pembahasan}

A. Redaksi dan Terjemahan Ayat-Ayat Tentang Membangun Konsep Harta Dalam Hukum Ekonomi Dan Bisnis

1. Q.S At-Taghabun ayat 14 dan 15

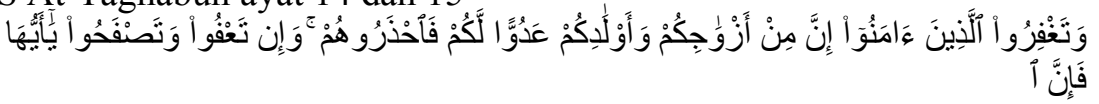

Artinya : Hai orang-orang mukmin, sesungguhnya di antara isteriisterimu dan anak-anakmu ada yang menjadi musuh bagimu maka berhatihatilah kamu terhadap mereka dan jika kamu memaafkan dan tidak memarahi serta mengampuni (mereka) maka sesungguhnya Allah Maha Pengampun lagi Maha Penyayang.

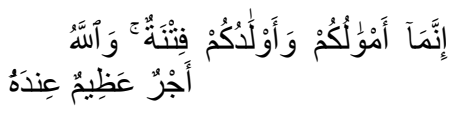

Artinya: Sesungguhnya hartamu dan anak-anakmu hanyalah cobaan (bagimu), dan di sisiAllah-lahpahalayangbesar.

2. Q.S Al-Kahfi ayat 46

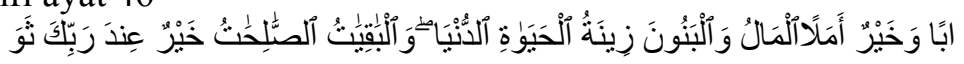

Artinya : Harta dan anak-anak adalah perhiasan kehidupan dunia tetapi amalan-amalan yang kekal lagi saleh adalah lebih baik pahalanya di sisi Tuhanmu serta lebih baik untukmenjadiharapan.

3. Q.S Al-Imran ayat 14

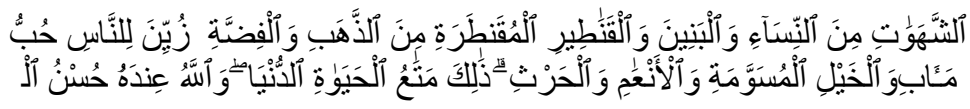

Artinya : Dijadikan indah pada (pandangan) manusia kecintaan kepada apa-apa yang diingini, yaitu: wanita-wanita, anak-anak, harta yang banyak dari jenis emas, perak, kuda pilihan, binatang-binatang ternak dan sawah ladang. Itulah kesenangan hidup di dunia, dan di sisi Allah-lah tempat kembali yang baik (surga). 


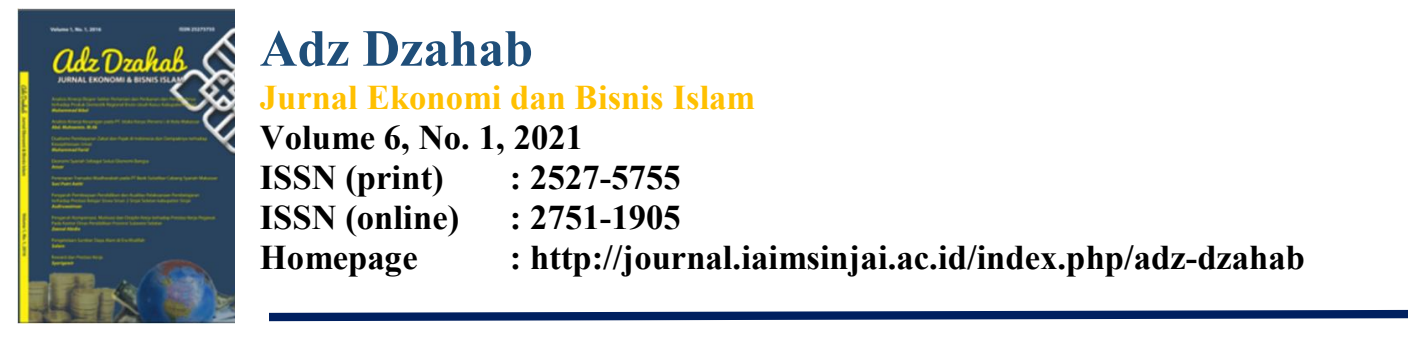

4. Q.S An-Nisa ayat 5

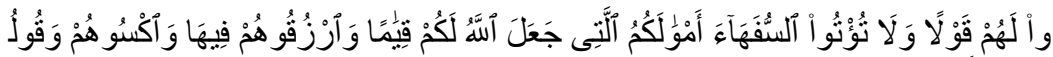

$$
\begin{aligned}
& \text { مَّعْروفًا }
\end{aligned}
$$

Artinya : Dan janganlah kamu serahkan kepada orang-orang yang belum sempurna akalnya, harta (mereka yang ada dalam kekuasaanmu) yang dijadikan Allah sebagai pokok kehidupan. Berilah mereka belanja dan pakaian (dari hasil harta itu) dan ucapkanlah kepada mereka kata-kata yang baik.

B. Sabab Al-Nuzul Dan Munasabah Ayat-Ayat Yang Membangun Konsep Harta dan Hukumnya Dalam Hukum Ekonomi Dan Bisnis

1. Surah At-Taghobun 64:14-15

Menurut Hadist Riwayat At-Turmudhiy bersumber dari Ibnu Abbas; bahwa ada seseorang yang menanyakan tentang ayat ini, maka beliau menjelaskan: mereka para tokoh dari penduduk Makkah telah memeluk Islam, dan mereka hendak menemui Nabi SAW, tetapi para istri dan anakanak mereka menolak ajakan mereka untuk melaksanakan hijrah. Kemudian setelah satu masa, ketika Nabi saw datang, mereka bersama istri dan anakanak mereka mengikuti ajakan untuk berhijrah,tetapi mereka telah melihat masyarakat banyak telah memahami agama, mendahului mereka, maka turunlah ayat ini, sebagaimana telah disunting riwayatnya oleh al-Wahidiy dalam kitabnya Asbab an-Nuzul, dan ia menyatakan bahwa ayat ini termasuk ayat Madaniyyah.

2. Surah At-Taghobun 64:15

Menurut Hadist Riwayat Ata' bin Yasar dan Ibnu Abbas R.A. ayat tersebut turun di Madinah mengenai kasus Auf bin Malik Al-Ashja'iy yang memiliki keluarga dan anak, pada saat ada perintah perang, dia selalu ditangisi dan diratapi oleh anak dan keluarganya, sehingga hal ini menghalangi dia menunaikan tugas perang, kasus ini lalu disampaikan kepada Nabi SAW, maka turunlah ayat tersebut.

3. Surah Al-Kahfi 18:46

Ayat ini tidak ada riwayat sabab nuzulnya, tetapi dari sisi munasabah atau korelasinya dengan ayat sebelumnya antara lain; ayat 45 menyebut tentang perumpaan kehidupan dunia yang fana, yang akan tiada arti dan lenyap, demikian juga harta kekayaan dan harta benda yang dibanggakan di dunia.

4. Surah Ali Imron 3:14

Ayat ini juga tidak ada sabab nuzulnya, maka dapat ditelusuri pemahaman maknanya dari korelasinya dengan ayat sebelum dan sesudahnya; misalnya cinta dunia adalah merupakan salah satu karakter orang-orang yang mengingkari anugerah Tuhan. Sehingga mampu melupakan hubungan seseorang dengan Tuhannya. Dan harta merupakan bagian dari hiasan dunia tersebut.

5. Surah An-Nisa' 4:5

Ayat ini juga tidak memiliki sabab nuzul, dengan mengkaji ayat sebelum dan sesudanya, maka dapat dipahami, bahwa harta adalah modal kehidupan bagi 


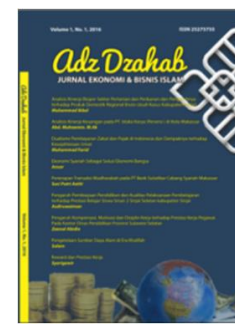

Adz Dzahab

Jurnal Ekonomi dan Bisnis Islam

Volume 6, No. 1, 2021

ISSN (print) : 2527-5755

ISSN (online) : 2751-1905

Homepage : http://journal.iaimsinjai.ac.id/index.php/adz-dzahab

kelayakan pihak yang berhak dan membutuhkan perlindungan atas martabat dan harkat penghidupan.

C. Kata Kunci Ayat dan Maknanya

1. Q.S At-Taghabun ayat 14 dan 15

Kata kunci untuk ayat ini merupakan peringatan dari Allah untuk orangorang yang beriman agar tidak terlalaikan atau "terpedaya oleh istri dan anak" karena sebagiannya ada yang menjadi musuh bagi mereka, yakni yang menghalangi mereka dari kebaikan. Oleh karena itu, sikap yang harus mereka lakukan adalah berwaspada, tetap melakukan perintah Allah, mengutamakan keridhaan-Nya karena di sisi-Nya ada pahala yang besar dan mengutamakan akhirat daripada dunia yang fana.

Maksudnya, terkadang istri atau anak dapat menjerumuskan suami atau ayahnya untuk melakukan perbuatan-perbuatan yang tidak dibenarkan agama atau menghalanginya dari mengerjakan kebaikan seperti berjihad dan berhijrah. Oleh karena larangan menaati istri dan anak jika di sana terdapat bahaya terhadap seorang hamba memberikan kesan agar bersikap keras kepada mereka, maka Allah Subhaanahu wa Ta'aala menghilangkan kesan ini dan memerintahkan mereka untuk memaafkan, tidak memarahi dan mengampuni mereka. Hal itu, karena sikap tersebut (memberi maaf) terdapat banyak maslahat.

Hal itu, karena balasan disesuaikan dengan jenis amalan. Barang siapa yang memaafkan, maka Allah akan memaafkannya, barang siapa yang mengampuni maka Allah akan mengampuninya, dan barang siapa yang bermu'amalah dengan Allah dengan amal yang dicintai-Nya, maka Allah akan mencintainya, demikian pula barang siapa yang bermu'amalah dengan manusia dengan amal yang dicintai mereka niscaya manusia mencintainya.

2. Q.S Al-Kahfi ayat 46

Kata kunci ayat ini merupakan "harta dan keturunan merupakan perhiasan dunia", sedangkan amal shalih dan zikir seperti tahlil, tasbih, dan tahmid lebih baik pahalanya dan lebih diharapkan balasannya di sisi Allah.

Maksudnya harta dan anak-anak yang digunakan untuk perhiasan di dunia tidak dijadikan untuk meraih keridhaan Allah, atau mereka bukanlah sesuatu yang dimanfaatkan untuk mendapat kehidupan akhirat. Akan tetapi amalan-amalan yang kekal lagi saleh yaitu segala amal kebaikan, baik itu yang diraih dengan mengeluarkan harta atau yang diraih dengan mengerahkan tenaga. Maka amalan itu akan tetap terjaga di sisi Allah. Dengan begitu, lebih baik pahalanya di sisi Tuhanmu yaitu lebih baik pahalanya daripada perhiasan dari harta dan anak keturunan, serta lebih banyak manfaatnya bagi pemiliknya.

3. Q.S Al-Imron ayat 14

Kata kunci ayat ini merupakan "kecintaan manusia terhadap apa yang diinginkannya", seperti wanita, anak-anak, harta yang berupa emas maupun perak, dan juga binatang ternak. Akan tetapi itu semua merupakan kesenangan dunia yang hanya bersifat fana. Dan hanya kembali disisi Allah lah merupakan tempat yang paling baik.

Maksud dari ayat ini adalah Allah mengabarkan tentang kondisi manusia ketika mendahulukan dunia atas akhirat, lalu antara kedua alam tersebut, di mana Allah mengabarkan bahwa manusia dihiasi dengan perkara-perkara tersebut hingga mereka meliriknya dengan mata mereka, dan mereka ilusikan manisnya dalam hati mereka, jiwa-jiwa mereka terbuai dalam kenikmatan-kenikmatannya. Seperti Syahwat yang menyenangkan hati itu dibuat menjadi sesuatu yang dicintai 


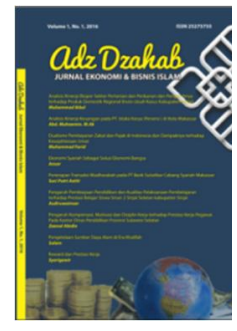

Adz Dzahab

Jurnal Ekonomi dan Bisnis Islam

Volume 6, No. 1, 2021

ISSN (print) : 2527-5755

ISSN (online) : 2751-1905

Homepage : http://journal.iaimsinjai.ac.id/index.php/adz-dzahab

oleh manusia, yaitu wanita yang untuk dinikmati dan membuat keturunan, anak laki-laki, harta melimpah yang telah terkumpul atau berlipat-lipat mencapai jumlah yang sangat banyak berupa emas, perak, kuda dari keturunan yang baik dan istimewa yang memiliki beberapa tanda, hewan-hewan ternak (unta, sapi, dan kambing) dan hasil pertanian.

Dan setiap kelompok dari manusia itu condong kepada salah satu jenis dari jenis-jenis kenikmatan tersebut, yang sebenarnya mereka telah menjadikannya sebagai cita-cita terbesar mereka dan puncak dari pengetahuan mereka. Padahal itu semua hanya kenikmatan yang sedikit yang akan lenyap dalam waktu yang sekejap, maka itulah "kesenangan hidup di dunia, dan di sisi Allah lah tempat kembali yang baik (surga).

4. Q.S An-Nisa ayat 5

Kata kunci ayat ini merupakan Allah "melarang para wali menyerahkan harta mereka yang belum sempurna akalnya agar harta itu tidak habis atau binasa". Hal itu, karena Allah menjadikan harta sebagai penopang hamba-hamba-Nya untuk maslahat dunia mereka maupun agama, mereka yang belum sempurna akalnya tidak dapat mengatur hartanya dan menjaganya.

Maksud ayat ini menjelaskan larangan menyerahkan harta mereka bila mereka belum mampu mengurus. Dan janganlah kalian serahkan kepada orang yang belum sempurna akalnya, yaitu anak yatim atau orang dewasa yang belum mampu mengurus, harta mereka yang ada dalam kekuasaan kalian yang dijadikan Allah sebagai pokok kehidupan, penyangga hidup, penopang urusan, dan penunjang berbagai keinginan dalam kehidupan ini. Sebab, dalam kondisi seperti itu mereka akan menghabiskan harta tersebut secara sia-sia. Oleh karena itu, wali mereka yang bertindak, yaitu dengan mengeluarkan harta untuk makan dan pakaian mereka, serta mengeluarkan untuk sesuatu yang darurat (penting) atau dibutuhkan mereka baik terkait dengan agama maupun dunia. Disandarkannya harta kepada para wali sebagai isyarat wajibnya bagi para wali memberlakukan harta anak yatim sebagaimana mereka memberlakukan harta mereka dengan menjaganya, bertindak tepat dan tidak membawa kepada hal-hal yang berbahaya.

D. Kandungan Hukum dan Konsep Harta Dalam Hukum Ekonomi dan Bisnis

1. Harta Sebagai Fitnah Ujian Keimanan

Harta merupakan nikmat dari Allah yang dengannya Dia menguji pemiliknya, apakah bersyukur atau kufur. Karena itu Allah menyebut harta sebagai fitnah, yaitu ujian dan cobaan. Allah berfirman dalam Surat At-Taghabun : 14-15.

Ayat tersebut terkandung isi seperti berikut (Hai orang-orang yang beriman! Sesungguhnya di antara istri-istri kalian dan anak-anak kalian ada yang menjadi musuh bagi kalian, maka berhati-hatilah kalian) janganlah kalian menaati mereka sehingga menyebabkan kalian ketinggalan tidak mau melakukan perbuatan yang baik, seperti berjihad dan berhijrah. Karena sesungguhnya latar belakang turunnya ayat ini adalah karena menaatinya (dan jika kalian meaafkan) mereka yang telah memperlambat kalian untuk melakukan perbuatan-perbuatan yang baik, karena alasan bahwa mereka merasa berat berpisah dengan kalian (dan tidak memarahi serta mengampuni, mereka, maka sesungguhnya Allah Maha Pengampun lagi Maha Penyayang). 


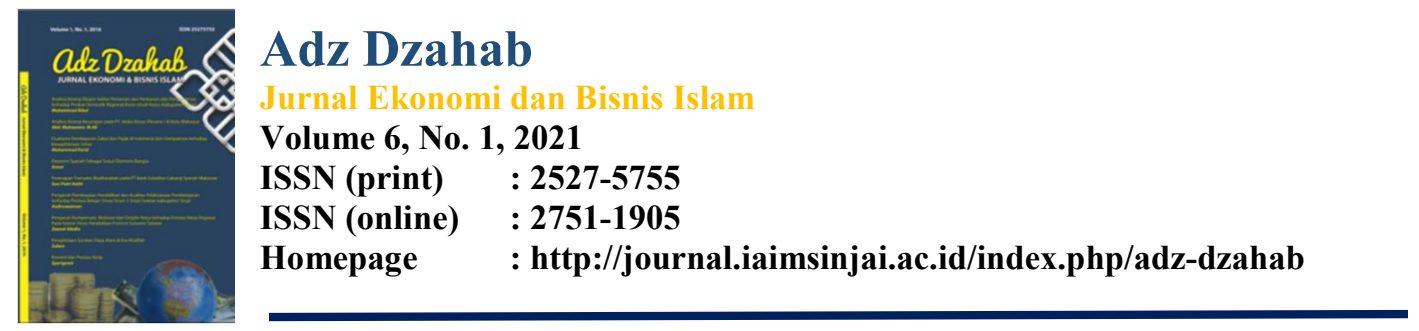

2. Harta Sebagai Hiasan Hidup (Perhiasan Dunia)

Manusia memiliki kecenderungan yang kuat untuk memiliki, menguasai, dan menikmati harta. Seperti dalam firman-Nya, Surat Al-Kahfi : 46 dan Ali Imran: 14.

Pada surat Al-Kahfi ayat 46, mengandung bahwa (Harta dan anak-anak adalah perhiasan kehidupan dunia) keduanya dapat dijadikan sebagai perhiasan di dalam kehidupan dunia (tetapi amalan-amalan yang kekal lagi saleh) yaitu mengucapkan kalimat: Subhaanallaah Wal Hamdulillaah Wa Laa Ilaaha Illallaah Wallaahu Akbar; menurut sebagian ulama ditambahkan Walaa Haulaa Walaa Quwwata Illaa Billaahi (adalah lebih baik pahalanya di sisi Rabbmu serta lebih baik untuk menjadi harapan) hal yang diharap-harapkan dan menjadi dambaan manusia di sisi Allah swt.

Dan pada surat Al-Imran ayat 14, mengandung bahwa menjadikan kecintaan pada jiwa mereka pada sesuatu tanpa melihat adanya kejelakan dan cela padanya. Selanjutnya adalah keinginan yang bersifat alami, seperti nafsu makan dan minum. kemudian harta yang banyak, bisa berupa emas dan perak. Dan juga kuda-kuda pilihan yang dijadikan tunggangan dalam peperangan. Dan binatang ternak semisal sapi, kambing onta dan lain-lain, adapun sawah di ladang sebagai tempat pertanian.

Syaikh Abdurrahman bin Nashir As-Sa'dy menyatakan bahwa Allahta'ala mengkhabarkan kepada kita bahwa Dia telah menghiasi bagi manusia kecintaan kepada dunia, khususnya pada harta benda yang telah disebutkan dalam ayat ini, karena semua itu adalah sebesar-besar syahwat (keinginan) sedangkan yang lainnya hanya mengikutinya.

3. Harta sebagai pegengan terhadap orang yang dapat mengelolanya

Harta akan dapat terkelola dengan baik, apabila berada pada tangan yang tepat. Seperti pada firman Allah surat An-Nisa : 5

Ayat tersebut mengandung bahwa Allah Ta'ala melarang memberikan kemungkinan kepada sufaha untuk mengelola harta kekayaan yang dijadikan Allah sebagai pokok kehidupan bagi manusia; harta yang diandalkan untuk menopang penghidupan mereka, seperti perdagangan dan semacamnya. Larangan itulah yang menjadi dasar perlindungan atas sufaha yang terdiri atas sufaha yang terdiri atas beberapa macam.

Sufaha dapat berupa anak kecil. Ia harus dilarang mengelola hartanya karena pertimbangan tidak dapat dijadikan patokan. Sufaha dapat berupa orang gila dan orang yang tidak cakap dalam mengelola harta lantaran kurang ilmu pengetahuan dan agamanya. Sufaha dapat berupa orang yang muflis, yaitu orang yang berhutang dan hartanya tidak mencukupi untuk membayar hutang. Jika orang yang berpiutang menagih kepada yang berhutang, maka hakim melarangnya menggunakan hartanya.

Konsep lain yang terknadung dalam 4 ayat diatas adalah:

1. Harta terbaik seorang muslim adalah harta yang mampu menjaga agamanya dari fitnah.

2. Harta harus didapatkan secara halal.

3. Harta harus dijadikan sebagai pokok kehidupan (qiyaman).

4. Harta harus berfungsi ekonomis, yakni memenuhi kebutuhan hidup.

5. Harta harus berfungsi sosial, yakni sebagai sarana saling membantu kebutuhan hidup bagi yang tidak mampu memenuhinya. 


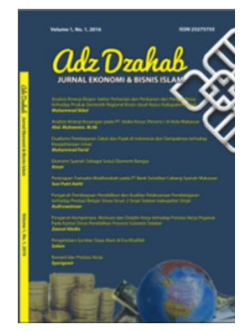

Adz Dzahab

Jurnal Ekonomi dan Bisnis Islam

Volume 6, No. 1, 2021

ISSN (print) : 2527-5755

ISSN (online) : 2751-1905

Homepage : http://journal.iaimsinjai.ac.id/index.php/adz-dzahab

E. Uraian Ayat-Ayat Yang Membangun Konsep Harta dan Hukumnya Dalam Hukum Ekonomi dan Bisnis

Harta dalam istilah Arab disebut dengan المال ميلا - yang berasal dari kata - memua arti condong, cenderung, dan miring, atau beraling dari tengah ke salah satu sisi Secara terminologi memuat makna "segala sesuatu yang menyenangkan manusia dan mereka pelihara, baik dalam bentuk materi maupun dalam bentuk manfaat".

1. Unsur Harta

Definisi di atas memberikan idikasi unsur utama harta adalah secara adat dan kebiasaan (tradisi) ia merupakan kebutuhan manusia yang memiliki nilai, baik berupa materi maupun bukan materi (manfaat), baik dapat disimpan dalam waktu lama ataupun tidak, baik dapat dimiliki secara individual, maupun kolektif. Jadi yang menetapkan nilai sesuatu tersebut adalah tradisi, situasi, atau kondisi suatu masyarakat.

2. Macam Harta dan Akibat Hukumnya

b. Harta ditinjau dari segi kebolehan memanfaatkannya menuut shara' terbagi menjadi:

1) Mal Mutaqawwim

"Segala sesuatu yang boleh dimanfaatkan menurut syara". Harta yang termasuk jenis ini adalah semua harta yang baik jenisnya, dan baik cara memperoleh dan penggunaannya, misalnya; kerbau halal dagingnya bila disembelih dengan cara yang sesuai petunjuk shari'ah.

2) Mal Ghairu Mutaqawwim

"Segala sesuatu yang tidak boleh dimanfaatkan menurut syara". Harta yang termasuk jenis ini adalah semua harta yang tidak boleh diambil manfaatnya, baik jenisnya, maupun cara memperoleh dan penggunaannya, misalnya; babi haram karena jenisnya, sepatu hasil curian haram karena cara memperolehnya, dan uang disumbangkan untuk dana pembangunan kasino haram karena penggunaannya yang tidak sesuai dengan petunjuk shari'ah. Pembagian ini merupakan inti pembagian harta dalam hukum Islam, karena harta yang memiliki peran, fungsi, dan memiliki akibat hukum dalam aktifitas atau transaksi yang dilakukan oleh seorang Muslim hanyalah harta yang masuk kategori pertama yaitu Mal Mutaqawwim.

c. Mal Mutaqawwim ditinjau dari segi ada atau tidak ada jenisnya di pasaran. Maka harta terbagi menjadi:

1) Harta Qimi

Sesuatu yang kurang dalam kesatuannya, karenanya tidak dapat berdiri sendiri tanpa (harus) ada perbedaan.

2) Harta Mitsli

Sesuatu yang ada persamaan dalam kesatuannya, dalam arti dapat berdiri sendiri tanpa menganggap ada perbedaan. Harta mitsliy adalah harta yang jenisnya secara persis dapat diperoleh di pasar, sedang harta qimi adalah jenis harta yang jenisnya sulit didapat di pasar, mungkin dapat diperoleh, tapi jenisnya berbeda, kecuali dalam hal harga. Misalnya karpet Bagdad diimpor oleh Indonesia, maka ia termasuk jenis harta qimi. 


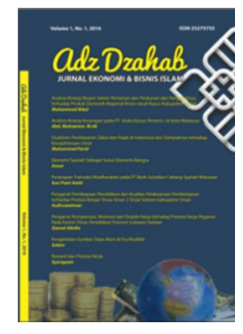

Kategorisasi ini termasuk relatif dan kondisional, sesuai kebutuhan dan kualitas masing-masing. Akibat hukum dari pembagian ini memuat ketentuan antara lain;

a) Tidak akan terjadi riba dalam harta qimi, karena jenis satuannya tidak sama, lain halnya dengan harta mitsliy.

b) Bila terikat dalam usaha bersama, maka masingmasing boleh mengambil bagian tanpa harus menunggu mitra usahanya, bila bagian itu berupa harta mitsliy, lain halnya dengan harta qimi.

c) Kerusakan yang terjadi pada harta mitsli harus diganti dengan harta mitsliy, tetapi harta qimi boleh mengganti dengan seharga nilainya.

d. Mal Mutaqawwim ditinjau dari segi pemanfaatannya terbagi menjadi:

1) Harta Istihlak

Sesuatu yang tidak dapat diambil kegunaan dan manfaatnya secara biasa, kecuali dengan menghabiskannya.

Harta jenis ini terbagi menjadi dua:

a) Harta Istihlak Haqiqi

Sesuatu baru dianggap harta, bila secara nyata zatnya habis digunakan dalam satu kali pakai, seperti; korek api.

b) Harta Istihlak Huquqi

Harta yang sudah habis nilainya, bila telah digunakan, tetapi zatnya masih utuh, hanya berpindah kepemilikannya, seperti uang bila dibayarkan untuk melunasi hutang.

2) Harta Isti'mal

Sesuatu yang dapat digunakan berulangkali dan materinya tetap terpelihara. Harta Isti'mal tidak habis sekali digunakan, tetapi dapat digunakan sesuai kebutuhan.

Akibat hukum dari pembagian ini hanya dari sisi akadnya saja. Harta Istihlak akadnya hanya bersifat saling menolong, sedangkan harta Isti'mal disamping bersifat saling menolong juga bisa dengan cara mengambil imbalan, seperti sewamenyewa dan sebagainya.

e. Mal Mutaqawwim ditinjau dari sisi jenisnya, maka harta terbagi menjadi:

1) Harta Manqul

Segala sesuatu yang dapat dipindahkan (begerak) dari satu tempat ke tempat lain.

2) Harta Ghairu Manqul

Segala sesuatu yang tidak dapat dipindahkan (begerak) dari satu tempat ke tempat lain.

Akibat hukum dari pembagian ini memuat ketentuan antara lain;

1) Adanya hak shuf'ah (hak istimewa yang dimiliki oleh seseorang terhadap harta yang akan dijual oleh seseorang, untuk mengajukan penawaran). Hak ini dimiliki oleh tetangga, dan mitra yang bersekutu dalam pemilikan. 


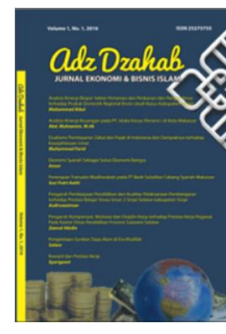

Adz Dzahab

Jurnal Ekonomi dan Bisnis Islam

Volume 6, No. 1, 2021

ISSN (print) : 2527-5755

ISSN (online) : 2751-1905

Homepage : http://journal.iaimsinjai.ac.id/index.php/adz-dzahab

2) Harta yang boleh diwakafkan hanya harta ghairu manqul (aqar), atau sulit dipisahkan dari aqar menurut Hanafiah, tetapi menurut Mayoritas Ulama kedua jenis harta tersebut boleh diwakafkan.

3) Harta ghairu manqul (aqar) milik anak yatim tidak boleh dijual kecuali dalam hal-hal yang amat mendesak bagi kebutuhan hidupnya.

4) Tidak ada gasab bagi harta ghairu manqul (aqar), menurut Hanafiah dan Imam Abu Yusuf. Ini berbeda dengan pendapat mayoritas ulama.

f. Mal Mutaqawwim ditinjau dari sisi materi dan bukan, maka harta terbagi menjadi:

1) Harta Ain

a) Harta Ain Dzati Qimah, yaitu benda yang memiliki bentuk yang dianggap sebagai harta karena memiliki nilai.

b) Harta Ain Ghairu Dzati Qimah, yaitu benda yang memiliki bentuk tetapi tidak dianggap sebagai harta karena tidak memiliki nilai atau harga, misalnya sebutir beras.

2) Harta Dain

Sesuatu yang berada dalam tanggung jawab.

3) Harta Nafi'

Sesuatu yang berangsur-angsur tumbuh menurut perkembangan waktu, karena itu ia tidak memiliki wujud dan tidak mungkin disimpan.

g. Mal Mutaqawwim ditinjau dari segi statusnya, maka harta terbagi menjadi:

1) Mal Al-Mamluk

Harta yang telah dimiliki, baik secara pribadi, maupun oleh badan hukum seeperti negara, organisasi kemasyarakatan.

Mal Al-Mamluk terbagi ke dalam 2 kategori:

a) Al-Mal Al-Mustaqil (harta perorangan/milik pribadi).

b) Al-Mal Al-Musyarokah (harta milik bersama).

Akibat hukum dari pembagian ini memuat ketentuan antara lain;

(1) Harta milik negara harus mempertimbangkan kepentingan rakyat, diatur dengan perundangundangan, rakyat juga tidak boleh merusak dan menjadikannya milik pribadi.

(2) Harta milik bersama harus mempertimbangkan keuntungan dan kepentingan bersama diatur dengan kesepakatan bersama, tanpa merusak dan merugikan pihak lain (mitranya).

(3) Harta milik pribadi, maka pemilik bebas menggunakannya sejalan dengan aturan shariat, dengan menjaga hak-hak pihak lain, dan tanpa merugikan pihak lain.

Al-Mal Al-musyarokah (harta milik bersama) bisa berubah status menjadi Al-Mal Al-Mustaqil (harta perorangan/milik pribadi) bila syarat-syarat pemilikan 


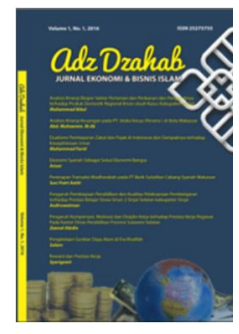

telah dipenuhi, demikian juga sebaliknya. Perubahan status tersebut dapat terjadi melalui;

(1) Kehendak sendiri dari pemilik, misalnya; dengan mewakafkan harta miliknya untuk kepentingan umum.

(2) Kehendak shara', misalnya; seseorang terlilit hutang negara dan tidak mau atau tidak mampu membayar sesuai dalam perjanjian, maka harta miliknya berubah status menjadi harta negara.

Al-Mal Al-Musyarokah (harta milik bersama) terbagi menjadi;

(1) Harta yang khusus diperuntukkan bagi kepentingan umum

(2) Harta yang khusus dieksploitasi bagi kepentingan umum

(3) Harta seseorang yang manfaatnya diperuntukkan bagi kepentingan umum.

Akibat hukum dari pembagian ini memuat ketentuan antara lain;

(1) Al-Mal Al-Musyarokah (harta milik bersama) tidak bisa dimiliki atau dikuasai oleh orang tertentu

(2) Seluruh hasil Al-Mal Al-Musyarokah (harta milik bersama) dapat dimanfaatkan secara bersama pula

(3) Al-Mal Al-Musyarokah (harta milik bersama) tidak dapat dijadikan sebagai jaminan utang orang tertentu

2) Al-Mal Al-Mubah

Sesuatu yang pada asalnya bukan milik seseorang, seperti air pada mata air, binatang buruan darat, laut, dan lain sebagainya, seperti pepohonan di hutan dan buahbuahannya.

Harta yang masuk kategori ini boleh diambil manfaatnya oleh siapapun menurut kemampuan usahanya, dengan tanpa merusak lingkungan dan potensi alam, dan sejalan dengan aturan syara'. Maka apa yang diambilnya tersebut telah menjadi hak miliknya.

3) Al-Mal al-Mahjur

Sesuatu yang oleh syara' tidak boleh dimiliki secara pribadi, dan tidak boleh diberikan kepada pihak lain secara pribadi. Sesuatu tersebut adakalanya karena sudah diwakafkan, dan adakalanya karena untuk kepentingan umum, seperti jalan raya, masjid, pemakaman dan lain sebagainya.

h. Al-Mutaqawwim ditinjau dari segi dapat dibagi dan tidak, maka harta terbagi menjadi:

1) Harta yang dapat dibagi, yaitu harta yang apabila dibagi maka ia tidak rusak dan manfaatnya tidak hilang. Pembagian tersebut tidak boleh menghilangkan manfaat dan tidak boleh merusak nilai harta.

2) Harta yang tidak dapat dibagi yaitu harta yang apabila dibagi maka ia akan rusak dan manfaatnya juga akan hilang.

Akibat hukum dari pembagian ini memuat ketentuan antara lain; 


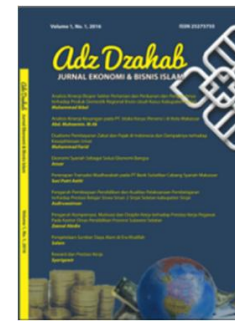

Adz Dzahab

Jurnal Ekonomi dan Bisnis Islam

Volume 6, No. 1, 2021

ISSN (print) $\quad: 2527-5755$

ISSN (online) : :2751-1905

Homepage : http://journal.iaimsinjai.ac.id/index.php/adz-dzahab

1) Terhadap Harta yang dapat dibagi, dapat diakukan eksekusi putusan hakim untuk membaginya. Sedang terhadap Harta yang tidak dapat dibagi, putusan hakim tidak dapat memaksa untuk membaginya, tetapi harus dilakukan berdasarkan kerelaan masing-masing pihak yang berhak atas harta iu

2) Harta yang tidak dapat dibagi, bila dihibahkan atau diwakafkan $1 / 3$ atau $1 / 2$, hukumnya sah. Sedang Harta yang dapat dibagi, bila dihibahkan atau diwakafkan $1 / 3$ atau $1 / 2$, hukumnya juga sah, hanya saja harus dilakukan pembagian terlebih dahulu.

3) Harta yang dapat dibagi, bila dimiliki secara bersama, dan salah satu pemilik mengeluarkan biaya untuk perawatan, bila dilakukan tanpa izin mitranya dan tanpa izin hakim, maka ia tidak berhak minta ganti rugi. Tetapi bila Hartanya tidak dapat dibagi, maka ia berhak meminta ganti rugi.

i. Mal Mutaqawwim ditinjau dari segi berkembang atau tidaknya, baik melalui upaya manusia, maupun dengan sendirinya, maka harta terbagi menjadi;

1) Harta Pokok/Modal (Asli), yaitu harta yang menghasilkan harta yang lain.

2) Harta Hasil/Untung, harta yang dihasilkan dari harta pokok.

Akibat hukum dari pembagian ini memuat ketentuan antara lain;

1) Harta Pokok yang diwakafkan tidak boleh dibagi kepada yang berhak menerima wakaf, tetapi Harta Hasil boleh dibagi.

2) Harta Pokok yang berstatus milik umum tidak boleh dibagi, tetapi Harta Hasil boleh dinikmati oleh siapapun.

3) Pemilik Harta Pokok otomatis menjadi pemilik Harta Hasil, misalnya; ada seseorang yang memiliki sebidang tanah yang di atasnya dibangun sebuah rumah dan di samping rumah ada sebuah pohon mangga gadung. Rumah dan pekarangan tersebut disewa oleh seseorang, maka penyewa berhak menikmati manfaat rumah dan buah mangganya. Demikian juga bila di tengah menyewakan rumah dan pekarangan tersebut, pemilik menjualnya kepada orang lain (pembeli), maka pembeli berhak menerima uang sewa rumah dan pekarangan tersebut.

F. Peranan Harta dalam bermuamalah

Harta pada hakikatnya adalah milik bersama, dalam arti ia harus beredar dan menghasilkan manfaat dan keuntungan bersama, bagi pembeli, bagi penjual, bagi menyewa, bagi yang bersedekah, bagi penerima sedekah dan lain sebagainya, semua hendaknya meraih keuntungan. Harta telah dijadikan oleh Allah sebagai pokok kehidupan (qiyaman) untuk manusia, karena itu ia harus dikembangkan, ia harus produktif dan menghasilkan keuntungan, sehingga biaya hidup hendaknya diambil dari hasil atau keuntungan pengelolaan harta pokok tersebut.

Meski demikian dalam pandangan al-Qur'an, modal tidak boleh menghasilkan dari dirinya sendiri, tapi hasilnya haruslah dari usaha baik manusia, karena itu riba dan perjudian dilarang. Dan salah satu ditetapkannya kadar tertentu dari zakat terhadap uang walau tidak dimanfaatkan, adalah dalam rangka mendorong aktivitas ekonomi, perputaran dana, serta sekaligus mengurangi spikulasi dan penimbunan. Harta harus berfungsi sosial, ia harus menjadi media yang membangun hubungan timbal balik yang harmonis. 


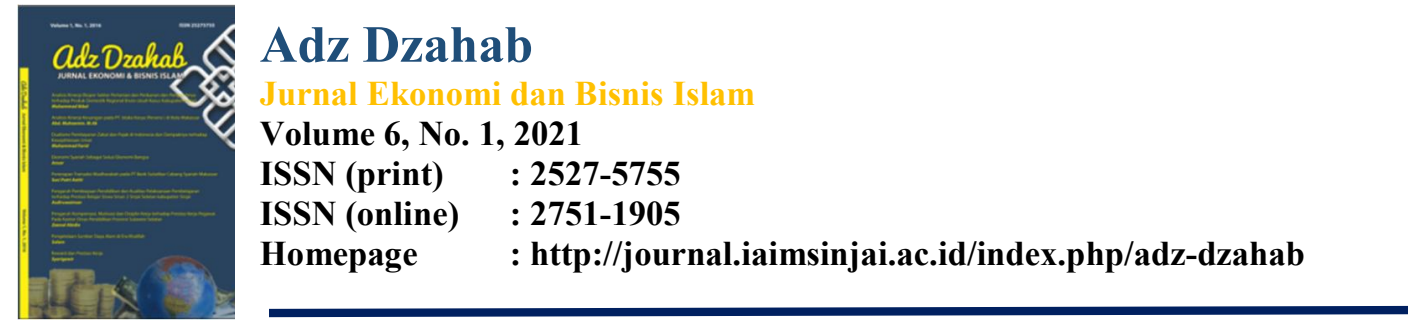

Selain itu harta memiliki peranan penting dalam dunia ekonomi, karena dalam dunia perekonomian selalu ada sangkut pautnya dengan harta. Didunia perekonomian harta adalah sesuatu yang biasa dijadikan alat tukar menukar dalam memenuhi kebutuhan ekonomi. Selain itu dalam dunia perbankan, harta adalah objek pertama yang harus ada di dalam bank. Karna saat kita berbicara bank pasti tak luput dari yang namanya harta atau uang. Sitematis dalam kegiatan perbankan yaitu memutar fungsi uang, dari menerima dana dalam bentuk simpanan lalu menyalurkannya kepada yang membutuhkan dalam bentuk pinjaman.

\section{Simpulan}

Harta adalah adalah suatu aset kekayaan kebendaan yang di butuhkan, di cari, dan di miliki oleh manusia. Harta juga sangat berguna bagi semua orang, karena dengan harta kekayaan manusia dapat memenuhi segala kebutuhan baik yang di inginkan atau yang sedang di butuhkan.

Di dalam harta terdapat konsep yaitu Sebagai Fitnah Ujian Keimanan, Sebagai Hiasan Hidup (Perhiasan Dunia), sebagai pegengan terhadap orang yang dapat mengelolanya. Yang terdapat dalam beberapa surah dalam Al-Quran yaitu Q.S At-Taghabun ayat 14 dan 15, Q.S Al-Kahfi ayat 46, Q.S Al-Imron ayat 14, dan Q.S An-Nisa ayat 5.

Harta ditinjau dari segi kebolehan memanfaatkannya menuut shara' terbagi menjadi: Mal Mutaqawwim, Mal Ghairu Mutaqawwim

1. Mal Mutaqawwim ditinjau dari segi ada atau tidak ada jenisnya di pasaran. Maka harta terbagi menjadi: Harta Qimi, Harta Mitsli

2. Mal Mutaqawwim ditinjau dari segi pemanfaatannya terbagi menjadi: Harta Isti'mal, Harta Istihlak : Harta Istihlak Haqiqi dan Harta Istihlak Huquqi,

3. Mal Mutaqawwim ditinjau dari sisi jenisnya, maka harta terbagi menjadi: Harta Manqul, Harta Ghairu Manqul

4. Mal Mutaqawwim ditinjau dari sisi materi dan bukan, maka harta terbagi menjadi: Harta Nafi', Harta Dain, Harta Ain : Harta Ain Dzati Qimah, Harta Ain Ghairu Dzati Qimah.

5. Mal Mutaqawwim ditinjau dari segi statusnya, maka harta terbagi menjadi: Mal Al-Mamluk: Al-Mal Al-Mustaqil (harta perorangan/milik pribadi) dan AlMal Al-Musyarokah (harta milik bersama). Al-Mal Al-Mubah dan Al-Mal alMahjur

6. Al-Mutaqawwim ditinjau dari segi dapat dibagi dan tidak, maka harta terbagi menjadi: harta yang dapat dibagi dan harta yang tidak dapat dibagi.

7. Mal Mutaqawwim ditinjau dari segi berkembang atau tidaknya, baik melalui upaya manusia, maupun dengan sendirinya, maka harta terbagi menjadi: Harta Pokok/Modal (Asli), yaitu harta yang menghasilkan harta yang lain dan Harta Hasil/Untung, harta yang dihasilkan dari harta pokok.

Harta harus berfungsi sosial, ia harus menjadi media yang membangun hubungan timbal balik yang harmonis. Harta memiliki peranan penting dalam dunia ekonomi, karena dalam dunia perekonomian selalu ada sangkut pautnya dengan harta. Didunia perekonomian harta adalah sesuatu yang biasa dijadikan alat tukar menukar dalam memenuhi kebutuhan ekonomi. 


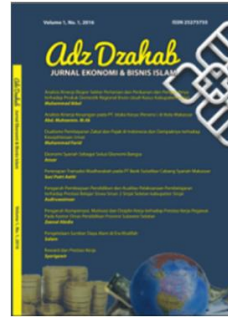

\section{Daftar Pustaka}

Sugiono. Metode Penelitian Kualitatif, Kualitatif dan R\&D. Cet. XI; Bandung: Alfabeta. 2010. Tahun 1994.

Al-Jazairy, Abu Bakar, Aisar Tafasir, Maktabah Al-'Ulum wa Al-hikam, Madinah,

Dinzaudin Djauwani.Pengantar Fiqih Muamalah.Jogjakarta.Pustaka Pelajar.2008

Ibnu Khatir, Tafsir Ibnu Khatir. Juz.8: 139. Tnp.:Mawqi' al-Tafsir,t.th Ibn Ashur, at-Tahrir wa at-Tanwir . Juz. 15:130. Tnp.:Mawqi' al-Tafasir,t.th.

Raziy, (ay), Tafsirar-Raziy, Juz.10:213. Tnp.:Mawqi' al-Tafasir,t.th.

An-Nafahat Al-Makkiyah / Syaikh Muhammad bin Shalih asy-Syawi. Diakses di https:/tafsirweb.com/10958-quran-surat-at-taghabun-ayat-14.html. Pada tanggal 5-102020, pukul 10.00 WIB.

Tafsir Al-Wajiz / Syaikh Prof. Dr. Wahbah az-Zuhaili, pakar fiqih dan tafsir negeri Suriah. Diakses di https://tafsirweb.com/4872-quran-surat-al-kahfi-ayat-46.html. Pada tanggal 5-10-2020, pukul 10.00 WIB.

Tafsir Al-Mukhtashar / Markaz Tafsir Riyadh, di bawah pengawasan Syaikh Dr. Shalih bin Abdullah bin Humaid (Imam Masjidil Haram. Diakses di https://tafsirweb.com/1146quran-surat-ali-imran-ayat-14.html. Pada tanggal 5-10-2020, pukul 10.00 WIB.

Zubdatut Tafsir Min Fathil Qadir / Syaikh Dr. Muhammad Sulaiman Al Asyqar, mudarris tafsir Universitas Islam Madinah. Diakses di https://tafsirweb.com/1537-quransurat-an-nisa-ayat-5.html. Pada tanggal 5-10-2020, pukul 10.00 WIB. 